\title{
Age as a Determinant of Livelihood Strategies and Poverty in Maroua
}

\section{Robert Nanche Billa}

Department of Sociology, Anthropology and Social Sciences for Development, Faculty of Arts, Letters and Social Sciences, University of Maroua, Cameroon

Email: nanchefile@yahoo.co.uk

\author{
Article History \\ Received: 23 December, 2021 \\ Revised: 26 January, 2022 \\ Accepted: 22 February, 2022 \\ Published: 27 February, 2022 \\ Copyright (C) 2022 ARPG \& \\ Author \\ This work is licensed under the \\ Creative Commons Attribution \\ International \\ (C) (1) CC BY: Creative \\ Commons Attribution License \\ 4.0
}

\begin{abstract}
The main question we asked in this work was: what is the state of the livelihood of the people of Maroua considering their high poverty rate (74\%) and an economic dependency ratio of 1.19 ? The main objective was to examine how age influences livelihood in Maroua in terms of income difference, subsistence resources, quality of life: feeding habits, health seeking behavior, number of persons per house, possession of mobile and immobile goods. We used the stratified sampling method, in which we administered 720 questionnaires to men and women ensuring that the percentage of females equal that of males as much as possible for easy comparison. We obtained the following results: those who are between 36-46 and 47-57 significantly produce millet, Niébé, groundnuts and other subsistence resources such as corn which significantly help them to survive. This is because those who are between 36-46 are significantly civil servants and farmers. Older persons only significantly produce millet and groundnut. This explains why those who are between 36-46 and 47-57 have a higher income than those who are older than them. Consequently, those who are between 36-46 years,47-57 years vary their meals more than four times per week because as compared to the other age groups they earn higher income per month and they produce or have nearly all the subsistence resources in Maroua. More so, the age group 47-48 stock more foods than the other age-groups.
\end{abstract}

Keywords: Subsistence; Mobile; Immobile goods; Health; Poverty; Eating habits.

\section{Introduction}

According to data from the 3rd census conducted in 2005 by the National Institute of Statistics, the population of the Far North was estimated at 3,111,792 inhabitants which was about $17.8 \%$ of the Cameroon's total population. According to the report on demographic projections and the estimates of priority targets for various health programs and interventions, carried out by the National Institute for Statistics (NIS) in 2016 states that, the total population of the Far North increased to about 4,208,433 inhabitants. This population is made up of 50.3\% women and $49.7 \%$ men. About $19.4 \%$ of the population is aged between 0 to 4 years, the age of 35.6\% varies from 5 to 14 years, $33.2 \%$ are of working age (15-64) and only $2.8 \%$ are at least 65 years old. Therefore, the Far North of Cameroon has a relatively younger population.

Considering the structure of the population by age, there emerges an economic dependency ratio of 1.19 . However, it is in the Diamaré division where there is relatively the largest number of people of working age in the Far North Region of Cameroon (about 49.6\%). There are about 8.1 percentage of widowed or divorced women in the Far North and about $10.4 \%$ in the Diamaré Division. In the Far North region about $1.2 \%$ of the people live with a disability and about $1.8 \%$ of them are in the Diamare division. The average household size in the region is 6.3 people.

In 2014, the poverty rate (or incidence of poverty) in the Far North region was 74.3\%; nearly double the national level. The poverty rate is higher in households headed by women $(81.2 \%)$ than in those headed by men (22.9\%). Poverty increases with the size of the household; rising from almost $28 \%$ in one-person per household to $86 \%$ in households of at least 8 people. The poverty rate seems to increase with the age of the head of household: $60.4 \%$ in households headed by a person under $35,76.9 \%$ in households headed by someone who is about 35 to 64 years old and $83.2 \%$ in households headed by a person who is 65 and above. The level of poverty decreases as the level of education of the head of household increases: from $81 \%$ in households where the head has no schooling to $33 \%$ in those where the head has a higher educational level. Households headed by inactive people are the poorest (78.6\%). The level of poverty among those headed by employed people is also high and stands at $74.2 \%$. Poverty is higher in households headed by people working in the primary sector $(85.1 \%)$ and the poverty rate is $64.3 \%$ and $32.1 \%$ in households where the head works in the secondary and tertiary sectors respectively.

About 96.5\% of workers were self-employed in 2016, in the Far North region of Cameroon. There is the lack of formal employment opportunities therefore; a majority of job seekers are generally employed in the informal sector, 
which is characterized by high levels of poverty, inequality and low-quality employment. Our objective is to find out how age determines income, level of education, profession and how they impact people's access to subsistence goods and the quality of their lives.

\section{Literature Review}

\subsection{Age and Livelihood}

According to Chambers and Conway (1992) a livelihood consists of the capabilities, assets (stores, resources, claims and access) as well as activities required for as means of living. A sustainable livelihood is "one which can cope with and recover from stress and shocks, maintain or enhance its capabilities and assets, and provide sustainable livelihood opportunities for the next generation; and which contributes net benefits to other livelihoods at the local and global levels and in the short and long-term'. Chambers (1995), considers it as 'the means of gaining living.' According to Scoones (2009), a livelihood is the contribution of the resources used and undertaken activities in order to live.

One of the important factors influencing the livelihood of rural people is land use. Cash, savings and credit are the basic indicators for livelihood assessment. Basic infrastructure and producer goods are the physical assets which are needed to support livelihoods. Livelihood strategy is an activity undertaken by smallholder households to provide a means of living. A key goal of livelihood strategies is to ensure household economic and social security (Koczberski et al., 2001). Further, the mixed livelihood strategy is an approach for capturing the diversified means of raising household income. Under the livelihood strategies, the rural livelihood strategy is always an attempt to diversify sources of income (Tittonell et al., 2010). The survival strategies they adopt depend on resource endowments, and in the context of the policy and institutional framework. Agricultural intensification, to achieve livelihood security, is a key livelihood strategy that rural people have adopted to diversify their incomes (Frank, 2000).

The factors that determine livelihood strategies are household assets. In addition to conventional assets like financial, natural, and physical capital (for example money, natural resources, and machines), household assets include various elements of human capital (e.g. skills, knowledge) and social capital (e.g. networks, associations).Access to these assets is determined and mediated by a large number of structures and processes (factors that either prevent or support people in gaining access to the livelihood assets), such as rules, laws, organizations, state agencies, etc. (Frank, 2000). Access is also influenced by contextual shocks (whether natural or man-made), trends (economic changes, technological developments, migration, etc.) and seasonality (weather and agricultural production). These are so-called vulnerabilities (Diana, 2003), factors that are outside a person's control but influence access to an asset. The available assets, the structures and processes, and the vulnerability context together form the basis on which people choose their livelihood strategies.

Diniz (2013) confirm that the Brazilian Amazon also undertake other activities such as crops (bean, rice, cassava, and corn) and small livestock (pigs, chickens, and goats) beside their main activity which is cattle rearing. Off-farm activities and sources of income relate mainly to off-farm labor and subsidies (pensions and family allowance). Moreover, environmental conditions, social organization, market availability, and some facilitating mechanisms of agrarian reform, i.e. credit policy, technological assistance, and land access, have all played key roles in directing the livelihood strategy choices toward (dairy) cattle breeding. In general, settlers achieve their livelihood goals, because they earn a relatively good income (national average). All in all, livelihood strategies adopted by settlers result from the combination of different factors, such as background and agrarian reform mechanisms, rather than from isolated factors.

Gasselin (2012), thinks that the outcomes of livelihood increase well-being, reduce vulnerability, and improve food security.

\section{Methodology}

We used the quota sampling method, by so doing we administered questionnaires to men and women ensuring that the percentage of females equal that of males as much as possible for easy comparison. We used the students who were doing the course called Data Collection in the department of Sociology, Anthropology and Social Sciences for Development at the Faculty of Letters, Arts and Social Sciences at the University of Maroua to administer the data. We identified all the neighborhoods in Maroua and the number of questionnaire administered in each quarter was determined by its size. That is more questionnaires were administered in bigger quarters than in smaller ones. They started from a particular household and then skip five households before selecting the next household. They either gave the respondents the questionnaire to fill for those who were literate or fill them for those who could neither read nor write. They administered questionnaires to 720 individuals:432 men (50.9\%) and 412 women $(49.1 \%)$ and we ensured that the main ethnic groups living in Maroua were represented in our sample: the peulh $(19.1 \%)$, the guiziga $(15.1 \%)$, the Moundang (12.7\%), the Tupuri (12.7\%), the Mafa (7.5\%), the Mofou (5.8\%), and other ethnic groups $(26.3 \%)$ mostly those who were from other regions but who were permanently living in Maroua for professional and other reasons. The percentage of the following age groups were represented in our sample: those between $25-30$ years $(46.6 \%)$ and 36-46 years $(22.3 \%)$, 47-57 years $(9.7 \%), 58-68$ years $(4.2 \%)$ and $.8 \%$ for those above 69 years because we have a predominantly youthful population in Maroua. We analyzed the collected data using SPSS software in order to cross-tabulate and describe variables. We put the value in red where the specific modality is above the general modality to show a significant relationship. 


\section{Method of Analysis}

The SPSS (statistical Package for Social Sciences) software which is a recognised program for analysing data in the social sciences was used to process our data. Attention was particularly paid to descriptive and inferential analyses. We presented each aspect of the operational framework in five stages: presentation of figures in table, followed by description of the tables and then interpretation and analysis. We did the inferential analysis by considering the chi-test and percentage technique in which we compared the specific category to the general population that is, the independent variable to the percentage obtained in the total population or sample and then explained their sociological implications.

\section{Presentation of Results}

In this section, we first of all present how age determines income, education, and occupation for us to better understand how it influences livelihood strategies such as availability of subsistence resources. Further more, we examine how age determines quality of life or poverty in the town of Maroua.

\subsection{Age as Determinants of Income, Level of Education and Occupation}

Here we examine how age determines how much one earns in Maroua in order to better explain how they influence subsistence resources and quality of life in Maroua.

Table-1. Age and Income in thousands

\begin{tabular}{|c|c|c|c|c|c|c|c|}
\hline \multirow{2}{*}{ Age } & \multicolumn{6}{|l|}{ Income } & \multirow[t]{2}{*}{ Total } \\
\hline & $<25$ & $26-51$ & $52-102$ & 103-153 & $>154$ & No income & \\
\hline \multirow{2}{*}{$<25$} & 51 & 21 & 11 & 9 & 8 & 1 & 101 \\
\hline & $26,6 \%$ & $15,2 \%$ & $8,0 \%$ & $8,7 \%$ & $9,9 \%$ & $12,5 \%$ & $15,3 \%$ \\
\hline \multirow{2}{*}{$25-35$} & 91 & 70 & 68 & 50 & 23 & 5 & 307 \\
\hline & $47,4 \%$ & $50,7 \%$ & $49,6 \%$ & $48,1 \%$ & $28,4 \%$ & $62,5 \%$ & $46,5 \%$ \\
\hline \multirow{2}{*}{$36-46$} & 26 & 27 & 41 & 28 & 26 & 1 & 149 \\
\hline & $13,5 \%$ & $19,6 \%$ & $29,9 \%$ & $26,9 \%$ & $32,1 \%$ & $12,5 \%$ & $22,6 \%$ \\
\hline \multirow{2}{*}{$47-57$} & 13 & 12 & 12 & 9 & 17 & 1 & 64 \\
\hline & $6,8 \%$ & $8,7 \%$ & $8,8 \%$ & $8,7 \%$ & $21,0 \%$ & $12,5 \%$ & $9,7 \%$ \\
\hline \multirow{2}{*}{$58-68$} & 11 & 6 & 4 & 8 & 4 & 0 & 33 \\
\hline & $5,7 \%$ & $4,3 \%$ & $2,9 \%$ & $7,7 \%$ & $4,9 \%$ & $0,0 \%$ & $5,0 \%$ \\
\hline \multirow{2}{*}{$>69$} & 0 & 2 & 1 & 0 & 3 & 0 & 6 \\
\hline & $0,0 \%$ & $1,4 \%$ & $0,7 \%$ & $0,0 \%$ & $3,7 \%$ & $0,0 \%$ & $0,9 \%$ \\
\hline \multirow[b]{2}{*}{ Total } & 192 & 138 & 137 & 104 & 81 & 8 & 660 \\
\hline & $100,0 \%$ & $100,0 \%$ & $100,0 \%$ & $100,0 \%$ & $100,0 \%$ & $100,0 \%$ & $100,0 \%$ \\
\hline
\end{tabular}

Table 1 shows that people below 25 and those who are between 25-35 significantly earn the lowest salary: below 25,000frs CFA. Those between 25-35 and those above 69 years earn higher than those below 25, they significantly earn between 25,000-35,000 firs CFA. The table equally shows that people between 25-35 and those between 36 - 46 years significantly earn between 52,000 - 102,000 FRS CFA. Equally, those between 25-35 and those between 36 - 46 including those who are between 58 - 68 significantly earn between 103,000 - 153,000 frs CFA. The table also demonstrates that three age groups significantly earn above $154,000 \mathrm{frs} \mathrm{CFA,} \mathrm{that} \mathrm{is,} \mathrm{those} \mathrm{who}$ are 36-46 years old, 47-57 years old and those above 69 years. Finally, people who are between 58- 68 years old significantly earn 103,000 - 153,000frs CFA. Curiously, those above 69 years earn significantly higher than those between 47-57 years and those in this age bracket also are significantly without income.

The following conclusions can be drawn from table 1: Firstly there are significant income varieties among two age groups, 25-35 and those between 36-46 with the former significantly having the lowest income and the latter the highest income. It can also clearly be observed in the table that the older one is, the higher income one will earn per month and vice versa. There is a very significant correlation between age and the amount of money one earns (Value $=73,984, \mathrm{DF}=25$ Asymp. Significance $=000$ ). Can this difference be due to difference in the level of education? 
Table-2. Age and Level of Education

\begin{tabular}{|c|c|c|c|c|c|c|c|c|}
\hline \multirow{2}{*}{$\begin{array}{l}\text { Age in } \\
\text { years }\end{array}$} & \multicolumn{8}{|c|}{ Levels of Education } \\
\hline & No Level & F.S.L.C & $\begin{array}{l}\text { Ordinary } \\
\text { Level }\end{array}$ & Probatoire & $\begin{array}{l}\text { Advanced } \\
\text { Level }\end{array}$ & Graduate & Postgraduate & Total \\
\hline \multirow{2}{*}{$<25$} & 8 & 19 & 28 & 15 & 33 & 21 & 1 & 125 \\
\hline & $8.69 \%$ & $19,6 \%$ & $22,4 \%$ & $23,1 \%$ & $20,0 \%$ & $15,9 \%$ & $2,0 \%$ & $17,2 \%$ \\
\hline \multirow{2}{*}{$25-35$} & 25 & 39 & 50 & 31 & 85 & 69 & 38 & 337 \\
\hline & $27.17 \%$ & $40,2 \%$ & $40,0 \%$ & $47,7 \%$ & $51,5 \%$ & $52,3 \%$ & $76,0 \%$ & $46,4 \%$ \\
\hline \multirow{2}{*}{$36-46$} & 21 & 19 & 33 & 15 & 29 & 31 & 8 & 156 \\
\hline & $22.83 \%$ & $19,6 \%$ & $26,4 \%$ & $23,1 \%$ & $17,6 \%$ & $23,5 \%$ & $16,0 \%$ & $21,5 \%$ \\
\hline \multirow{2}{*}{$47-57$} & 21 & 13 & 11 & 2 & 13 & 8 & 1 & 69 \\
\hline & $22.83 \% \%$ & $13,4 \%$ & $8,8 \%$ & $3,1 \%$ & $7,9 \%$ & $6,1 \%$ & $2,0 \%$ & $9,5 \%$ \\
\hline \multirow{2}{*}{$58-68$} & 15 & 5 & 3 & 2 & 5 & 2 & 1 & 33 \\
\hline & $16.30 \%$ & $5,2 \%$ & $2,4 \%$ & $3,1 \%$ & $3,0 \%$ & $1,5 \%$ & $2,0 \%$ & $4,5 \%$ \\
\hline \multirow{2}{*}{$>69$} & 2 & 2 & 0 & 0 & 0 & 1 & 1 & 6 \\
\hline & $2.17 \%$ & $2,1 \%$ & $0,0 \%$ & $0,0 \%$ & $0,0 \%$ & $0,8 \%$ & $2,0 \%$ & $0,8 \%$ \\
\hline \multirow{2}{*}{ Total } & 92 & 97 & 125 & 65 & 165 & 132 & 50 & 726 \\
\hline & $100,0 \%$ & $100,0 \%$ & $100,0 \%$ & $100,0 \%$ & $100,0 \%$ & $100,0 \%$ & $100,0 \%$ & $100,0 \%$ \\
\hline
\end{tabular}

Table 2 demonstrates that significant levels of no education are significantly concentrated between the age brackets: 36 - 46 years, $47-57$ years, $58-68$ years and $>69$ years. However, those who are between $36-46$ years old are also significantly ordinary, probatoire holders and graduates. Contrarily, residents in Maroua who are above 47 years old are not significantly graduates; they have either not significantly gone to school or have the primary school level. Young people below 25 years old are significantly primary school leavers, Ordinary, Probatoire and advanced level holders and they are not significantly graduates nor postgraduates. Those who are adequately educated are people between 25 - 35 years old because they are significantly holders of probatoire , Advanced Level and first degree. The number of them who have not gone to school or who are first school leavers or Ordinary or BEPC holders is not significant.

To conclude, one can say that the younger one is in Maroua, the higher the probability that one has obtained a higher educational level and vice versa. This may be due to the fact that the Maroua University was created in 2007 and the younger generation of the people of Maroua had the opportunity to go to school which the older generation did not have and had to travel to other parts of Cameroon like Ngoundéré and Yaounde to do graduate and postgraduates studies. Considering the above data one notices that education is not a significant determinant of income in the town of Maroua because as table one indicates, the older one is, the higher one earns. This means that younger people earn lower than older persons although they are more educated than them. (Value $=142,756, \mathrm{DF}=40, \mathrm{Asymp}$. Significance $=000)$.

Table-3. Age and Occupation

\begin{tabular}{|c|c|c|c|c|c|c|c|}
\hline \multirow{2}{*}{ Age group } & \multicolumn{6}{|l|}{ Occupation } & \multirow[t]{2}{*}{ Total } \\
\hline & Civil Servants & $\begin{array}{l}\text { Farming } \\
\text { /cattle rearing }\end{array}$ & Artists & Trader & Jobless & $\begin{array}{l}\text { Informal } \\
\text { Sector }\end{array}$ & \\
\hline \multirow{2}{*}{$<25$} & 13 & 26 & 3 & 16 & 17 & 45 & 120 \\
\hline & $5,5 \%$ & $30,2 \%$ & $20,0 \%$ & $13,8 \%$ & $29,3 \%$ & $23,7 \%$ & $16,9 \%$ \\
\hline \multirow{2}{*}{$25-35$} & 111 & 28 & 9 & 56 & 31 & 94 & 329 \\
\hline & $46,8 \%$ & $32,6 \%$ & $60,0 \%$ & $48,3 \%$ & $53,4 \%$ & $47,3 \%$ & $46,4 \%$ \\
\hline \multirow{2}{*}{$36-46$} & 78 & 23 & 3 & 19 & 6 & 24 & 153 \\
\hline & $32,9 \%$ & $26,7 \%$ & $20,0 \%$ & $16,4 \%$ & $10,3 \%$ & $12,9 \%$ & $21,6 \%$ \\
\hline \multirow{2}{*}{$47-57$} & 28 & 5 & 0 & 12 & 2 & 21 & 68 \\
\hline & $11,8 \%$ & $5,8 \%$ & $0,0 \%$ & $10,3 \%$ & $3,4 \%$ & $9,7 \%$ & $9,6 \%$ \\
\hline \multirow{2}{*}{$58-68$} & 5 & 4 & 0 & 12 & 1 & 11 & 33 \\
\hline & $2,1 \%$ & $4,7 \%$ & $0,0 \%$ & $10,3 \%$ & $1,7 \%$ & $5,4 \%$ & $4,7 \%$ \\
\hline \multirow{3}{*}{$>69$} & 2 & 0 & 0 & 1 & 1 & 2 & 6 \\
\hline & $0,8 \%$ & $0,0 \%$ & $0,0 \%$ & $0,9 \%$ & $1,7 \%$ & $1,1 \%$ & $0,8 \%$ \\
\hline & 237 & 86 & 15 & 116 & 58 & 197 & 709 \\
\hline Total & $100,0 \%$ & $100,0 \%$ & $100,0 \%$ & $100,0 \%$ & $100,0 \%$ & $100,0 \%$ & $100,0 \%$ \\
\hline
\end{tabular}

Table 3 indicates that middle age persons (people between 36-46 and 47-57) are significantly civil servants, that is, they work in the public sector while farming and cattle rearing is significantly done by people younger than 25 years and those between 36-46 years and artists are significantly people below 36 years ( below 25 and 25-35)., trading is significantly done by those between $25-35$ and $58-68$ years old. It also demonstrates that jobless and workers of the informal sector are significantly people below 36 years and people above 69 years.

Compared to other age groups, there is a lot of variety among those who are relatively younger, that is, those who are below 25 and between 25-35 years. The former significantly do farming and art works and are also jobless as well as work in the informal sector while the later, are artists, traders and just like the former, they are also jobless 
and work in the informal sector. These two age groups share many things together; they are significantly artists, jobless and informal sector workers. As table 2 also indicates, there are significant income varieties among the two age groups, 25-35 and those between 36- 46 because of the varieties of activities that they do.

Equally, those who are above 69 years are significantly jobless and informal sector workers. This is clear because many of them are on retirement and for them to survive they have to do some activities in the informal sector. Those who are 58-68 years are only significantly traders. Those who are between 47-57 are also only significantly civil servants while those who are between $36-46$ are not only significantly civil servants but also farmers. This explains why as seen in table 2 they earn the highest income monthly. This means that, the older one becomes, the less active he becomes in income generating activities and the younger one is, the more income generating activities he does. Younger people significantly diversify their economic activities. The main objective of this work is to explain how level of education, income and occupation varieties influence people's livelihood in Maroua.

\subsection{Age and Subsistence Resources}

In this section we examine whether age influences the availability of subsistence resources and the stocking of subsistence resources which are either cultivated or bought.

\subsubsection{Age as a Determining Factor of Availability Subsistence Resources}

Table-4. Age and Subsistence Resources

\begin{tabular}{l|l|l|l|l|l}
\hline Age in years & \multicolumn{4}{|l|}{ Age and availability of foodstuff } & \multirow{2}{*}{ Total } \\
\cline { 2 - 6 } & Millet & Groundnut & Niébé & Other food stuffs & \\
\hline \multirow{2}{*}{25} & 41 & 32 & 22 & 31 & 87 \\
\hline \multirow{2}{*}{$25-35$} & $12,9 \%$ & $14,7 \%$ & $13,8 \%$ & $21,1 \%$ & $16.57 \%$ \\
\hline \multirow{2}{*}{$36-46$} & 145 & 87 & 68 & 52 & 231 \\
\cline { 2 - 6 } & $45,6 \%$ & $39,9 \%$ & $42,8 \%$ & $35,4 \%$ & $44 \%$ \\
\hline \multirow{2}{*}{$47-57$} & 81 & 61 & 46 & 40 & 126 \\
\hline \multirow{2}{*}{$58-68$} & $25,5 \%$ & $28,0 \%$ & $28,9 \%$ & $27,2 \%$ & $24 \%$ \\
\hline \multirow{2}{*}{69} & 32 & 24 & 18 & 17 & 52 \\
\cline { 2 - 6 } & $10,1 \%$ & $11,0 \%$ & $11,3 \%$ & $11,6 \%$ & $9.90 \%$ \\
\hline \multirow{2}{*}{ Total } & 17 & 12 & 5 & 6 & 26 \\
\hline & $5,3 \%$ & $5,5 \%$ & $3,1 \%$ & $4,1 \%$ & $4.95 \%$ \\
\cline { 2 - 5 } & 2 & 2 & 0 & 1 & 3 \\
\hline
\end{tabular}

These are the main crops that are cultivated in the Far North Region of Cameroon. More people produce millet in Maroua because it is easier to produce it than maize. The soil is not well-adapted to the production of maize because it will need more care and more inputs like fertilizer. That is why we chose millet, groundnuts and niebé as the main subsistence resources. Table 4 indicates that middle age persons, that is those who are between $36-46$ and 47 - 57 significantly produce all the above because as we have seen above, those who are between 36 - 46 are significantly civil servants and farmers so it is not surprisingly for them to significantly have all the foodstuff for their subsistence. Older persons only significantly produce millet and groundnut while younger persons significantly produce other crops apart from those that are produced in the Far North Region of Cameroon. This explains why those who are between $36-46$ and $47-57$ have a higher income than those who are older than them.

\subsubsection{Stocking of Food as a Strategy of Livelihood}

About $82.56 \%$ of the population of Maroua stock food and only $12.33 \%$ do not. Here we examine how age influences the type of food that people stock in the town of Maroua. 
The Journal of Social Sciences Research

Table-5. Age and the stocking of Food

\begin{tabular}{|c|c|c|c|c|c|c|c|}
\hline & \multicolumn{6}{|c|}{ STOCKED FOODS } & \multirow[t]{2}{*}{ Total } \\
\hline & Millet & Végétales & Tubercules & Maîze & Rice & Others & \\
\hline \multirow{2}{*}{$<25$} & 41 & 42 & 32 & 53 & 47 & 13 & 99 \\
\hline & $14,7 \%$ & $19,7 \%$ & $15,8 \%$ & $17,2 \%$ & $16,5 \%$ & $19,7 \%$ & $17.71 \%$ \\
\hline \multirow{2}{*}{$25-35$} & 132 & 96 & 91 & 131 & 134 & 31 & 255 \\
\hline & $47,3 \%$ & $45,1 \%$ & $45,0 \%$ & $42,5 \%$ & $47,2 \%$ & $47,0 \%$ & $45.62 \%$ \\
\hline \multirow{2}{*}{$36-46$} & 70 & 42 & 43 & 77 & 53 & 14 & 122 \\
\hline & $25,1 \%$ & $19,7 \%$ & $21,3 \%$ & $25,0 \%$ & $18,7 \%$ & $21,2 \%$ & $21.82 \%$ \\
\hline \multirow{2}{*}{$47-57$} & 21 & 21 & 22 & 33 & 35 & 7 & 54 \\
\hline & $7,5 \%$ & $9,9 \%$ & $10,9 \%$ & $10,7 \%$ & $12,3 \%$ & $10,6 \%$ & $9.67 \%$ \\
\hline \multirow{2}{*}{$58-68$} & 13 & 10 & 12 & 13 & 13 & 1 & 26 \\
\hline & $4,7 \%$ & $4,7 \%$ & $5,9 \%$ & $4,2 \%$ & $4,6 \%$ & $1,5 \%$ & $4.65 \%$ \\
\hline \multirow{2}{*}{$>69$} & 2 & 2 & 2 & 1 & 2 & 0 & 3 \\
\hline & $0,7 \%$ & $0,9 \%$ & $1,0 \%$ & $0,3 \%$ & $0,7 \%$ & $0,0 \%$ & $.53 \%$ \\
\hline Total & 279 & 213 & 202 & 308 & 284 & 66 & 559 \\
\hline
\end{tabular}

Table 5 indicates that millet is significantly stocked by those who are between $25-35$ years, 36 - 46 years and $>69$ years because those who are above 25 years significantly farm it. The table also shows that those who are between 47-57 and those who are above 69 significantly stocked a variety of food stuff. However, those who are between 47-57 stocked more foodstuff than those who are above 69. Equally, those who are between $25-35$ stocked as much food stuff as those who are between58 - 68. Those who stock fewer foodstuffs in the town of Maroua are those who are below 25 years and 36-46 years. Below we examine how the availability of subsistence resources and the stocking of food influence the number and variety of meals one eats per day.

\subsection{Age and Quality of Life}

In this section we examine how age influences people's quality of life in terms of number of times one eats per day and the variation of meals per day.. Equally, we examine how age influences domestic comfort in terms of the possession of durable goods.

\subsubsection{Age as Determinant of Feeding Habits and Health Seeking Behavior}

Table-6. Age and Number of meals per day

\begin{tabular}{|c|c|c|c|c|c|c|c|}
\hline & \multicolumn{6}{|c|}{ Number of meals } & \multirow[t]{2}{*}{ Total } \\
\hline & 0 time & 1 time & 2 times & 3 times & 4 times & $>4$ times & \\
\hline \multirow{2}{*}{$<25$ year } & 6 & 5 & 29 & 64 & 7 & 2 & 113 \\
\hline & $50,0 \%$ & $13,2 \%$ & $16,8 \%$ & $15,7 \%$ & $25,0 \%$ & $14,3 \%$ & $16,8 \%$ \\
\hline \multirow{2}{*}{$25-35$ years } & 5 & 23 & 85 & 181 & 13 & 7 & 314 \\
\hline & $41,7 \%$ & $60,5 \%$ & $49,1 \%$ & $44,4 \%$ & $46,4 \%$ & $50,0 \%$ & $46,7 \%$ \\
\hline \multirow{2}{*}{$36-46$ years } & 0 & 5 & 38 & 96 & 4 & 3 & 146 \\
\hline & $0,0 \%$ & $13,2 \%$ & $22,0 \%$ & $23,5 \%$ & $14,3 \%$ & $21,4 \%$ & $21,7 \%$ \\
\hline \multirow{2}{*}{47 - 57 years } & 0 & 4 & 13 & 42 & 2 & 2 & 63 \\
\hline & $0,0 \%$ & $10,5 \%$ & $7,5 \%$ & $10,3 \%$ & $7,1 \%$ & $14,3 \%$ & $9,4 \%$ \\
\hline \multirow{2}{*}{58 - 68 years } & 1 & 1 & 8 & 19 & 2 & 0 & 31 \\
\hline & $8,3 \%$ & $2,6 \%$ & $4,6 \%$ & $4,7 \%$ & $7,1 \%$ & $0,0 \%$ & $4,6 \%$ \\
\hline \multirow{2}{*}{$>69$ years } & 0 & 0 & 0 & 6 & 0 & 0 & 6 \\
\hline & $0,0 \%$ & $0,0 \%$ & $0,0 \%$ & $1,5 \%$ & $0,0 \%$ & $0,0 \%$ & $0,9 \%$ \\
\hline \multirow{2}{*}{ Total } & 12 & 38 & 173 & 408 & 28 & 14 & 673 \\
\hline & $100,0 \%$ & $100,0 \%$ & $100,0 \%$ & $100,0 \%$ & $100,0 \%$ & $100,0 \%$ & $100,0 \%$ \\
\hline
\end{tabular}

Table 6 indicates that two groups of persons (those below 25 and those between 58-68 severely suffer from hunger because they significantly hardly eat once per day. This category is certainly made up of children who have left their parents and are probably living alone since the phenomenon of street children is very high in Maroua due to the social crisis which Maroua is currently going through such as Boko Haram. However, those below 25 years also have a category of persons who significantly eat four times per day. Therefore, there is a huge inequality among these children in the city, that is, those who basically have nothing and those who have in abundance. In the same light, there are also persons who are between 58 -68 who significantly feed themselves three and four times per day. The above differences are merely random variation because there is absolutely no statistical differences between age and the number of times one feeds per day. (Value $=25,550, \mathrm{Df}=25$, Asymp. Significance $=., 432$ ) 
Table-7. Age and the variation of meals per week

\begin{tabular}{|c|c|c|c|c|c|c|}
\hline \multirow[t]{2}{*}{ Age in years } & \multicolumn{5}{|c|}{ Number of variation per week } & \multirow{2}{*}{ Total } \\
\hline & One time & Two times & Three times & Four times & $>$ four times & \\
\hline \multirow{2}{*}{$<25$} & 12 & 35 & 32 & 26 & 8 & 113 \\
\hline & $16,9 \%$ & $18,5 \%$ & $15,7 \%$ & $18,7 \%$ & $15,7 \%$ & $17,3 \%$ \\
\hline \multirow{2}{*}{$25-35$} & 38 & 78 & 105 & 62 & 22 & 305 \\
\hline & $53,5 \%$ & $41,3 \%$ & $51,5 \%$ & $44,6 \%$ & $43,1 \%$ & $46,6 \%$ \\
\hline \multirow{2}{*}{$36-46$} & 11 & 46 & 40 & 29 & 11 & 137 \\
\hline & $15,5 \%$ & $24,3 \%$ & $19,6 \%$ & $20,9 \%$ & $21,6 \%$ & $20,9 \%$ \\
\hline \multirow{2}{*}{$47-57$} & 5 & 22 & 16 & 11 & 7 & 61 \\
\hline & $7,0 \%$ & $11,6 \%$ & $7,8 \%$ & $7,9 \%$ & $13,7 \%$ & $9,3 \%$ \\
\hline \multirow{2}{*}{$58-68$} & 4 & 7 & 10 & 10 & 2 & 33 \\
\hline & $5,6 \%$ & $3,7 \%$ & $4,9 \%$ & $7,2 \%$ & $3,9 \%$ & $5,0 \%$ \\
\hline \multirow{2}{*}{$>69$} & 1 & 1 & 1 & 1 & 1 & 5 \\
\hline & $1,4 \%$ & $0,5 \%$ & $0,5 \%$ & $0,7 \%$ & $2,0 \%$ & $0,8 \%$ \\
\hline \multirow{2}{*}{ Total } & 71 & 189 & 204 & 139 & 51 & 654 \\
\hline & $100,0 \%$ & $100,0 \%$ & $100,0 \%$ & $100,0 \%$ & $100,0 \%$ & $100,0 \%$ \\
\hline
\end{tabular}

Table 7 shows that the category of people that significantly suffer from the variation of meals are younger persons especially those between 25-35 years and older persons those who are between 58-68 and those above 69.. This is because as compared to the other age grade, they earn quite lower because they significantly work in the informal sector. The age grade that suffer the most here is the one between 25-35 because they hardly vary their feeding above three times per week while those who are between 58-68 vary their meals between once and four times per week. Those below 25 years significantly vary their meals between two and four times while those who are between 36-46 vary theirs between two and more than four times per week.

The table clearly shows that those who significantly vary their meals more than four times per week are those who are between 36-46 years,47-57 years because as compared to the other age groups they earn higher income per month and they produced or have nearly all the subsistence resources in Maroua and particularly the age group 47-48 stocked more foods than the other age-groups. It is quite interesting to note that much older persons especially those who are on retirement, that is, those between $58-68$ and those above 69 years significantly vary their meals once because the former earn lower income and only significantly do trading to survive. However, the above are just random variation because there is statistically no significant correlation between age and variation of meals (Value $=13,241, \mathrm{df}=20$, Asymp. Siignificance $=, 867$ ).

Table-8. Age and Health Seeking Behaviour

\begin{tabular}{|c|c|c|c|c|c|c|}
\hline \multirow[t]{2}{*}{ Age in years } & \multicolumn{6}{|c|}{ Methods of Treating one's Health } \\
\hline & Traditional Treatment & Hospital & Street & $\begin{array}{l}\text { Traditonal / } \\
\text { hospital }\end{array}$ & Street/Hospital & Total \\
\hline \multirow{2}{*}{$<25$} & 29 & 34 & 5 & 41 & 15 & 124 \\
\hline & $22,3 \%$ & $13,6 \%$ & $12,9 \%$ & $17,4 \%$ & $22,7 \%$ & $17,2 \%$ \\
\hline \multirow{2}{*}{$25-35$} & 52 & 121 & 21 & 109 & 33 & 336 \\
\hline & $40,0 \%$ & $48,4 \%$ & $61,3 \%$ & $46,4 \%$ & $50,0 \%$ & $46,5 \%$ \\
\hline \multirow{2}{*}{$36-46$} & 28 & 64 & 4 & 46 & 13 & 155 \\
\hline & $21,5 \%$ & $25,6 \%$ & $9,7 \%$ & $19,6 \%$ & $19,7 \%$ & $21,5 \%$ \\
\hline \multirow{2}{*}{$47-57$} & 17 & 18 & 8 & 24 & 1 & 68 \\
\hline & $13,1 \%$ & $7,2 \%$ & $16,1 \%$ & $10,2 \%$ & $1,5 \%$ & $9,4 \%$ \\
\hline \multirow{2}{*}{$58-68$} & 4 & 11 & 3 & 12 & 3 & 33 \\
\hline & $3,1 \%$ & $4,4 \%$ & $0,0 \%$ & $5,1 \%$ & $4,5 \%$ & $4,6 \%$ \\
\hline \multirow{2}{*}{$>69$} & 0 & 2 & 1 & 3 & 1 & 6 \\
\hline & $0,0 \%$ & $0,8 \%$ & $0,0 \%$ & $1,3 \%$ & $1,5 \%$ & $0,8 \%$ \\
\hline \multirow{2}{*}{ Total } & 130 & 250 & \begin{tabular}{|l|}
40 \\
\end{tabular} & 235 & 66 & 722 \\
\hline & $100,0 \%$ & $100,0 \%$ & $100,0 \%$ & $100,0 \%$ & $100,0 \%$ & $100,0 \%$ \\
\hline
\end{tabular}

Table 8 indicates that those who significantly seek formal treatment when they are sick are those who are between 36-46 years. They do not significantly take a variety of treatments like those who are between 25-35. This category of persons significantly goes to the hospital and also consults street doctors and equally, a significant number of them combine street and hospital treatments. That is, people who start treating themselves at home and as the illness worsens, they then go to the hospital for formal or modern treatment. However, the latter treat themselves better than the other age categories. This is due to other factors rather than income because those who are between 47-57 years significantly earn better than those who are 36 -46 but the latter have a better health treatment than the former.

However, the others do not significantly go to the hospital when they are sick because they do not have sufficient money, so they start to cure themselves either by first of all buying some drugs from the street or consulting a traditional doctor. It is quite interesting to note that the younger generation significantly combines drugs 
from the street and hospital. That is, when they are sick, they first of all buy drugs from the street and when automedication fails, they then seek the expertise of a medical doctor. The older generation significantly joins traditional and modern treatments, that is, when they are sick, they will consult a native doctor and if the illness persists, they then consult a medical doctor for the treatment. Therefore, generation plays a role in the choice of where one treats oneself when one is sick while the younger generation prefers street doctors, the older generation prefers a traditional doctor. However, those who are much older that is, those who are above 69 years, are caught between, that is, they either significantly combine street medication with either hospital or traditional treatment. In either case, it is interesting to note that they end up in the hospital. There is a statistical relationship between age and health-seeking

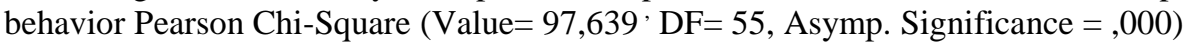

\subsubsection{Age and Domestic Comfort}

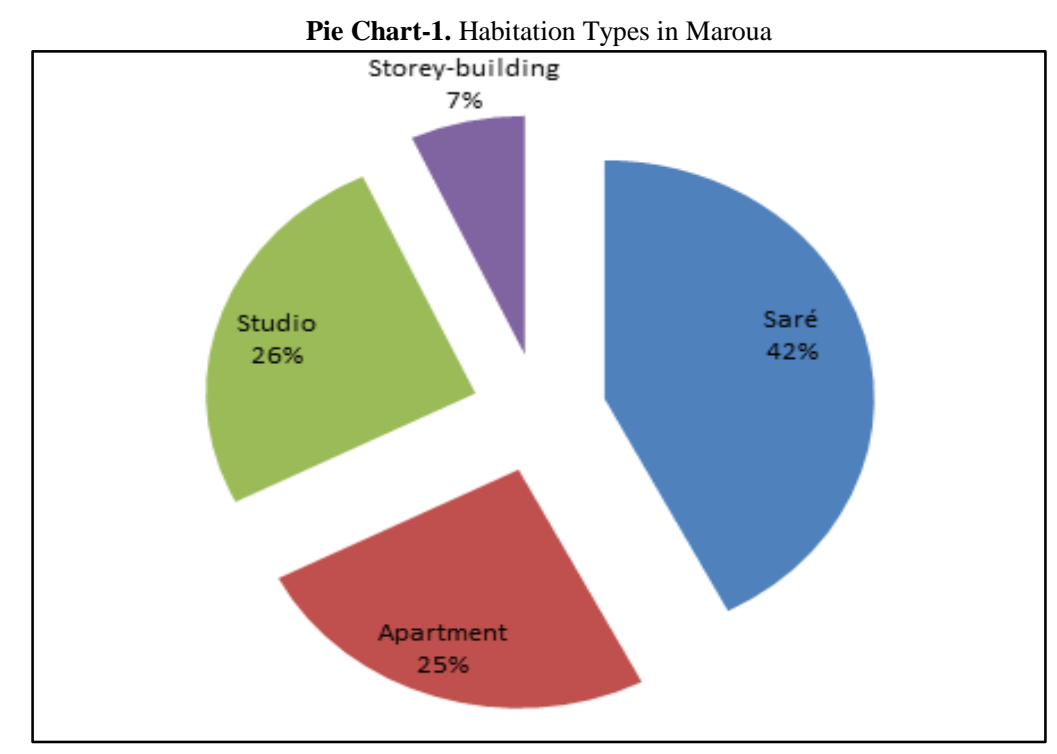

Pie charrt 1 shows that $42 \%$ of the population of Maroua lives in a traditional house called saré and about $26 \%$, $25 \%$ and $7 \%$ of them live in a studio, apartment and storey building respectively. This shows that there is a serious housing problem in Maroua. Of those who live in a saré, we significantly have those who are below 25 years, middle-age persons ( $47-57$ years) and those who are retired ( 58-68 years). Those who are 36 - 46 years, and above 69 years significantly live in apartments. Studios are significantly occupied by young people who are below 25 years and between 25 - 35 years because they are predominantly people of school-going age, and are significantly single and poor. Although young people do not significantly live in apartments and storey buildings and people above 36 significantly live in apartments and storey-buildings, there is no statistical relation between type of housing and age. Pearson Chi-Square (Value $=45,231^{\prime} \mathrm{DF}=25$, Asymp. Significance $=, 008$ )

As concerned age and the quality of one's house we discovered that only $16.28 \%$ of the population has a modern kitchen. This is because about $45 \%$ live in Sare which is not modern. Apart from those who are above 69 years, the rest have significantly got a modern kitchen. However, those who are between 25-35 and 58-68, significantly possess an internal modern kitchen and those who are between 25-35 and 36-46 significantly possess an external modern kitchen. A fenced house is significantly possessed by older persons, that is, those who are between 47-57 years, 58-68 years and above sixty years.

Although older persons do not significantly possess a modern external kitchen and they significantly possess a fenced house, there is absolutely no correlation between age and the quality of ones residence. Pearson Chi-Square (Value $=26,143, \mathrm{DF}=20$, Asymp. Significance $=, 161$ ). 
Histogram-1. Percentage of Number of Persons per Room

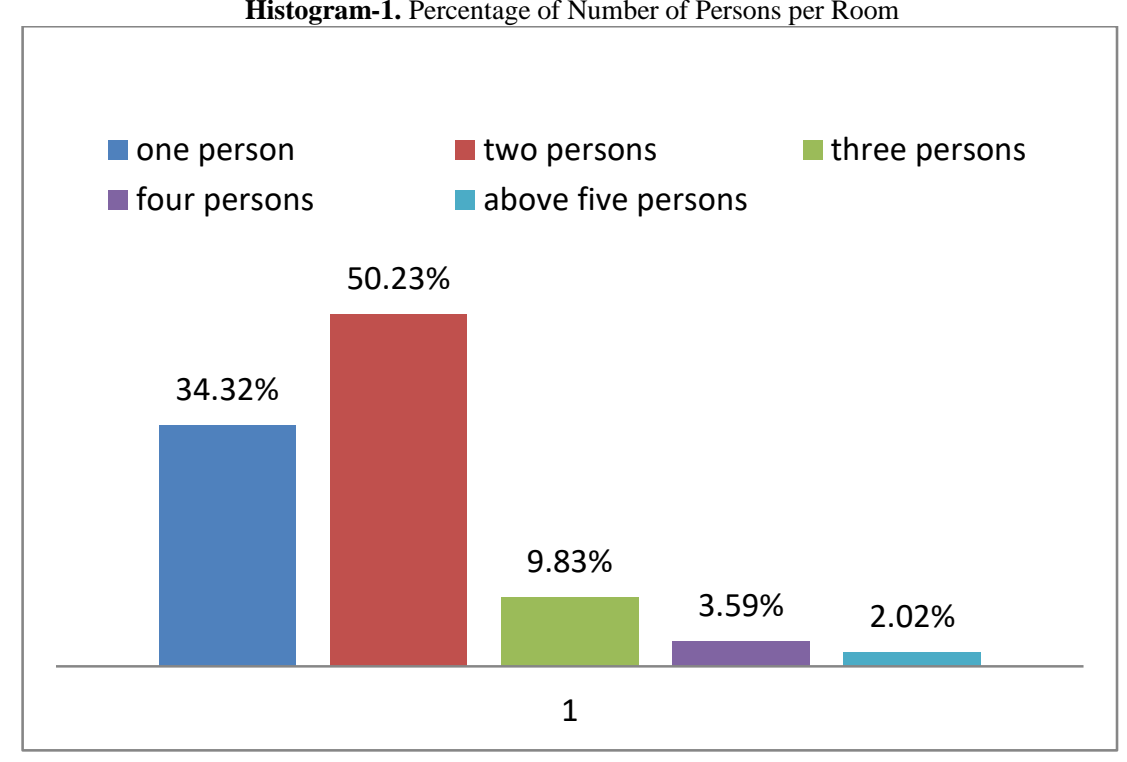

The above histogram indicates that one person lives in a room in only about $34.32 \%$ of the households in Maroua, and in about $50.23 \%$ of the households, two persons share a room and about $9.33 \%, 3.59 \%, 2.02 \%$ of the households in the town of Maroua have about three, four and above five persons per room respectively.

In households where the head is below 25 years and between 47-57, one person significantly lives in a room They do not significantly have households where two or more persons inhabit a room. However, the age-groups: 25 35 and 36-46 have a lot of significant variations, that is, they significantly have people who have households where two, three and above five persons live in a room for people between 25-35 years, about two, four and above five persons for the age-group 36-37 years share a room. Only the above two age-groups significantly have households which have more than five persons per room. The age-group 58-68 do not significantly have households with only one or two persons inhabiting it, they significantly have three and four persons inhabiting a room and do not significantly have five persons per room: (Value=32,222 $\mathrm{DF}=35$, Asymp. Significance =,,603).

\subsubsection{Age and Possession of Durable Goods}

Table-9. Age and Possession of Fixed Durable Goods

\begin{tabular}{|c|c|c|c|c|c|c|c|}
\hline \multirow[t]{2}{*}{ Age } & \multicolumn{6}{|c|}{ Possession of Durable Goods } & \multirow[t]{2}{*}{ Total } \\
\hline & None & Refrigerator & Television & Telephone & Computer & Other & \\
\hline \multirow{2}{*}{$<25$} & 9 & 32 & 55 & 73 & 36 & 11 & 106 \\
\hline & $16,4 \%$ & $13,1 \%$ & $14,1 \%$ & $15,2 \%$ & $15,9 \%$ & $21,2 \%$ & $17.04 \%$ \\
\hline \multirow{2}{*}{$25-35$} & 29 & 99 & 176 & 230 & 104 & 26 & 290 \\
\hline & $52,7 \%$ & $40,6 \%$ & $45,0 \%$ & $47,9 \%$ & $45,8 \%$ & $50,0 \%$ & $46.622 \%$ \\
\hline \multirow{2}{*}{$36-46$} & 14 & 63 & 96 & 106 & 47 & 5 & 132 \\
\hline & $25,5 \%$ & $25,8 \%$ & $24,6 \%$ & $22,1 \%$ & $20,7 \%$ & $9,6 \%$ & $21.22 \%$ \\
\hline \multirow{2}{*}{$47-57$} & 2 & 34 & 44 & 46 & 28 & 7 & 60 \\
\hline & $3,6 \%$ & $13,9 \%$ & $11,3 \%$ & $9,6 \%$ & $12,3 \%$ & $13,5 \%$ & $9.65 \%$ \\
\hline \multirow{2}{*}{$58-68$} & 1 & 13 & 17 & 22 & 8 & 3 & 30 \\
\hline & $1,8 \%$ & $5,3 \%$ & $4,3 \%$ & $4,6 \%$ & $3,5 \%$ & $5,8 \%$ & $4.82 \%$ \\
\hline \multirow{2}{*}{$>69$} & 0 & 3 & 3 & 3 & 4 & 0 & 4 \\
\hline & $0,0 \%$ & $1,2 \%$ & $0,8 \%$ & $0,6 \%$ & $1,8 \%$ & $0,0 \%$ & $0.64 \%$ \\
\hline Total & \begin{tabular}{|l|}
55 \\
$100,0 \%$
\end{tabular} & $\begin{array}{l}244 \\
100,0 \%\end{array}$ & $\begin{array}{l}391 \\
100,0 \%\end{array}$ & \begin{tabular}{|l|}
480 \\
$100,0 \%$
\end{tabular} & \begin{tabular}{|l|}
227 \\
$100,0 \%$
\end{tabular} & \begin{tabular}{|l|}
52 \\
$100,0 \%$
\end{tabular} & \begin{tabular}{|l|}
622 \\
$100,0 \%$
\end{tabular} \\
\hline
\end{tabular}

Table 9 clearly shows that there is really an inequality in the age group $36-46$ with a lot of significant variations of the possession of durable goods. Younger people especially those below 25 years do not significantly possess the major durable goods but significantly possess other durable goods apart from those mentioned in the table. Those between 25 -35 years significantly possess only a telephone. After all, a telephone is now affordable and nearly everyone can afford it. They are significantly among those who possess no durable goods. Those who are older, significantly possess more durable goods Apart from those who are above 69 years, all the categories above 35 years significantly possess a refrigerator. Apart from those who are between 58-68, all the other categories significantly possess a television. Curiously, only middle-age persons (25 - 35 and $36-46)$ significantly possess a telephone.

What is also intriguing is that those who are significantly more educated, that is, those between $25-35$ years old do not significantly possess a computer. Instead, those who significantly possess a computer are those who are older. $47-57$, and those above 69 years old. It is worthy of note here that middle age persons $(36-46$ and $47-57)$ 
significantly possess more durable goods than the other categories. This is not a coincidence because they significantly earn above 154,000frs CFA. Although those above 69 years also significantly earn above 154,000frs CFA, they only significantly possess a telephone and a computer. Those between $58-68$ years old and those who are between 25 - 35 only significantly possess one durable good: a refrigerator and a telephone respectively.

Table-10. Age and Possession of Mobile Goods

\begin{tabular}{|c|c|c|c|c|c|}
\hline & \multicolumn{4}{|c|}{ Possession of mobile goods } & \multirow[t]{2}{*}{ Total } \\
\hline & Bicycle & Motor Cycle & Car & Other & \\
\hline \multirow{2}{*}{$<25$} & 20 & 52 & 11 & 19 & 87 \\
\hline & $16,3 \%$ & $16,9 \%$ & $11,0 \%$ & $15,6 \%$ & $16.26 \%$ \\
\hline \multirow{2}{*}{$25-35$} & 56 & 133 & 32 & 56 & 236 \\
\hline & $45,5 \%$ & $43,2 \%$ & $32,0 \%$ & $45,9 \%$ & $44.11 \%$ \\
\hline \multirow{2}{*}{$36-46$} & 31 & 71 & 24 & 31 & 125 \\
\hline & $25,2 \%$ & $23,1 \%$ & $24,0 \%$ & $25,4 \%$ & $23.36 \%$ \\
\hline \multirow{2}{*}{$47-57$} & 13 & 33 & 21 & 11 & 58 \\
\hline & $10,6 \%$ & $10,7 \%$ & $21,0 \%$ & $9,0 \%$ & $10.84 \%$ \\
\hline \multirow{2}{*}{$58-68$} & 3 & 17 & 10 & 5 & 26 \\
\hline & $2,4 \%$ & $5,5 \%$ & $10,0 \%$ & $4,1 \%$ & $4.86 \%$ \\
\hline \multirow{2}{*}{$>69$} & 0 & 2 & 2 & 0 & 3 \\
\hline & $0,0 \%$ & $0,6 \%$ & $2,0 \%$ & $0,0 \%$ & $0.56 \%$ \\
\hline Total & 123 & 308 & 100 & 122 & 535 \\
\hline
\end{tabular}

Table 10 shows that those who are between 36 - 46 years possess more mobile durable goods than the other age categories: they significantly possess a bicycle, a car and other mobile durable goods. The other age groups significantly possess less number of mobile goods: those below 25 and those between 58 -68 as well as those above 69 years significantly possess a motor cycle and a car while those between 25-35 significantly own a bicycle and other durable goods. People who significantly suffer are the residents of Maroua who are between 47-57 because they significantly possess only car. However, as compared to the others, they significantly possess more fixed durable goods than the other age categories. Residents who are between 36-46 are those who significantly possess more fixed and mobile goods in the town of Maroua because they significantly earn more than the others. However, other factors play in the consumption of durable goods rather just income because those who are between $47-57$ significantly earn above 154,000 frs CFA and do not have a variety of significant levels of income but they own less number of durable goods than those who are between 36-46.

The above table also shows that the possession of a car is not influenced by income because nearly all the income categories possess it except those between $25-35$. A motorcycle is significantly possessed by the younger generation those below 25 and the older generation those above 58 years while bicycle is significantly possess by the younger generation: those who are $25-35$ and $36-37$. It is worth noting that the younger generation significantly possesses other mobile goods that the older generation does not have.

Table-11. Age and Possession of Immobile Goods

\begin{tabular}{|c|c|c|c|c|c|c|c|}
\hline \multirow[t]{2}{*}{ Age } & \multicolumn{6}{|c|}{ Immobile Goods } & \multirow[t]{2}{*}{ Total } \\
\hline & None & Land & House & Garden & Farm & Others & \\
\hline \multirow{2}{*}{25} & 41 & 36 & 31 & 13 & 23 & 7 & 101 \\
\hline & $28,7 \%$ & $15,1 \%$ & $11,4 \%$ & $14,9 \%$ & $14,3 \%$ & $13,5 \%$ & $17.1 \%$ \\
\hline \multirow{2}{*}{$25-35$} & 77 & 105 & 98 & 32 & 55 & 23 & 269 \\
\hline & $53,8 \%$ & $43,9 \%$ & $35,9 \%$ & $36,8 \%$ & $34,2 \%$ & $44,2 \%$ & $4544 \%$ \\
\hline \multirow{2}{*}{$36-46$} & 16 & 59 & 75 & 23 & 49 & 13 & 128 \\
\hline & $11,2 \%$ & $24,7 \%$ & $27,5 \%$ & $26,4 \%$ & $30,4 \%$ & $25,0 \%$ & 21.62 \\
\hline \multirow{2}{*}{$47-57$} & 6 & 29 & 43 & 13 & 22 & 6 & 62 \\
\hline & $4,2 \%$ & $12,1 \%$ & $15,8 \%$ & $14,9 \%$ & $13,7 \%$ & $11,5 \%$ & $10.47 \%$ \\
\hline \multirow{2}{*}{$58-68$} & 3 & 8 & 22 & 4 & 12 & 3 & 28 \\
\hline & $2,1 \%$ & $3,3 \%$ & $8,1 \%$ & $4,6 \%$ & $7,5 \%$ & $5,8 \%$ & $4.73 \%$ \\
\hline \multirow{2}{*}{69} & 0 & 2 & 4 & 2 & 0 & 0 & 4 \\
\hline & $0,0 \%$ & $0,8 \%$ & $1,5 \%$ & $2,3 \%$ & $0,0 \%$ & $0,0 \%$ & $0.68 \%$ \\
\hline Total & 143 & 239 & 273 & 87 & 161 & 52 & 592 \\
\hline
\end{tabular}

Table 11 shows that younger people do not significantly possess immobile goods such as land, house, garden, farm and others. These goods are significantly possess by middle age people, that is those who are between $36-46$ and $47-57$ while those who are between 58 -68 significantly possess only a house and a farm. They possess less immobile goods as compared to those who are above 69 years old who significantly possess a land, a house and a garden. This explains why those who are between 36-46 and 47 - 57 possess more subsistence goods because they significantly possess more land than the other categories. It is interesting to note that those who significantly own land also significantly possess a garden and a farm. 
Those who are younger (below 25 years and 36- 46) significantly get their possession through inheritance. Apart from those who are below 25 years, the rest significantly purchase the goods using their savings. We discovered that middle-age persons do not take loans, that is, those who are between $36-46$ and 47 - 57 while those who are younger, that is, below 36 years and above 57 years significantly take loans to buy these goods. Those who are between $36-46$ significantly buy theirs through inheritance and savings while those who are between $47-57$ mostly through purchase and endownment. There is significantly no correlation between age and the means used to obtain the mobile and immobile goods (value $=46,042, \mathrm{DF}=30$, Asymp. Sig. $(2$-sided $)=, 031$ )

Table-12. How the immobile and mobile Goods help them

\begin{tabular}{l|l|l|l|l|l|l}
\hline \multirow{2}{*}{ Age } & \multicolumn{4}{l}{ Comment ces biens immobiliers vous aident-ils? } & Total \\
\cline { 2 - 7 } & Transportation & Source of Income & Sport & Prestige & Other & \\
\hline \multirow{2}{*}{$<$} & 68 & 21 & 5 & 4 & 7 & 105 \\
\cline { 2 - 7 } & $16,9 \%$ & $16,8 \%$ & $26,3 \%$ & $23,5 \%$ & $28,0 \%$ & $17,7 \%$ \\
\hline \multirow{2}{*}{$25-35$} & 190 & 50 & 6 & 6 & 9 & 261 \\
\cline { 2 - 7 } & $47,1 \%$ & $40,0 \%$ & $31,6 \%$ & $35,3 \%$ & $36,0 \%$ & $43,9 \%$ \\
\hline \multirow{2}{*}{$36-46$} & 85 & 35 & 5 & 1 & 6 & 132 \\
\cline { 2 - 7 } & $21,1 \%$ & $28,0 \%$ & $26,3 \%$ & $5,9 \%$ & $20,0 \%$ & $22,2 \%$ \\
\hline \multirow{2}{*}{$47-57$} & 38 & 11 & 3 & 5 & 3 & 60 \\
\cline { 2 - 7 } & $9,4 \%$ & $8,8 \%$ & $15,8 \%$ & $29,4 \%$ & $4,0 \%$ & $10,1 \%$ \\
\hline \multirow{2}{*}{$58-68$} & 18 & 8 & 0 & 0 & 5 & 30 \\
\cline { 2 - 7 } & $4,5 \%$ & $6,4 \%$ & $0,0 \%$ & $0,0 \%$ & $8,0 \%$ & $5,1 \%$ \\
\hline \multirow{2}{*}{69} & 4 & 0 & 19 & 17 & 1 & 6 \\
\cline { 2 - 7 } & $1,0 \%$ & $0,0 \%$ & $100,0 \%$ & $100,0 \%$ & $100,0 \%$ & $100,0 \%$ \\
\hline \multirow{2}{*}{ Total } & 403 & 125 & & & $3,0 \%$ & $1,0 \%$ \\
\hline
\end{tabular}

Table 12 shows that mostly youth use their goods for transportation, that is why they significantly possess bicycle that can help them to move from one end of the town to the other. This is because as compared to adolescent and middle age people, they relatively earn lower and lack the means to travel from one part of the town to the other. Adolescent, those between $36-46$ and those between 36-46 use theirs as a source of income. This is because they significantly own land, farm, houses and gardens which are rented by landless people in order to farm on, to live in and to grow vegetables like salad, tomatoes etc and sell them to make some money. Young people below 25 years, adolescents, that is those between 36 - 46 years and retired people, that is, people who are between 58 - 68 years use theirs to do sport. It is worth-noting that the latter significantly have a motor cycle while the former ones significantly have bicycles. Therefore they use both motorcycles and bicycles to do sport.

We also discover that people below 25years and those between $47-57$ and those above 69 use theirs as prestige. That means, the goods becomes an object of conspicuous consumption, that is, used to show-off ones wealth and to distinguish oneself from other persons. We found that considerably younger persons; middle-age persons and older persons buy these goods for prestige. What is surprising is that younger persons despite their lowincome still afford to buy luxury goods. However, the others significantly earn good salary above 154,000 frs CFA. Nanche (2021) shows that women in the town of Maroua mostly buy cars to show-off. The above show that there is a relationship between age and reasons why they possess both mobile and immobile goods. Pearson Chi-Square (Value $=49,965, \mathrm{DF}=30$, Asymp. Sig. $(2$-sided $)=, 013$ )

Table-13. Age and how immobile and mobile Goods Impact Children's Life

\begin{tabular}{l|l|l|l|l|l|l|l}
\hline \multirow{2}{*}{ Age } & \multicolumn{6}{l}{ Impactent le Children's Life } & \multicolumn{3}{l}{ Total } \\
\cline { 2 - 8 } & School Fees & Leisure & Travelling & Healthcare & Feeding & Others & \\
\hline \multirow{2}{*}{25} & 24 & 16 & 11 & 8 & 10 & 6 & 75 \\
\cline { 2 - 8 } & $12,8 \%$ & $23,9 \%$ & $13,8 \%$ & $25,8 \%$ & $18,2 \%$ & $28.57 \%$ & $17,0 \%$ \\
\hline \multirow{2}{*}{$25-35$} & 74 & 31 & 32 & 14 & 24 & 7 & 182 \\
\cline { 2 - 8 } & $39,6 \%$ & $46,3 \%$ & $40,0 \%$ & $45,2 \%$ & $43,6 \%$ & 33.33 & $41,3 \%$ \\
\hline \multirow{2}{*}{$36-46$} & 51 & 15 & 16 & 8 & 12 & 2 & 104 \\
\cline { 2 - 9 } & $27,3 \%$ & $22,4 \%$ & $20,0 \%$ & $25,8 \%$ & $21,8 \%$ & $9.52 \%$ & $23,6 \%$ \\
\hline \multirow{2}{*}{$47-57$} & 26 & 3 & 12 & 0 & 5 & 3 & 49 \\
\cline { 2 - 8 } & $13,9 \%$ & $4,5 \%$ & $15,0 \%$ & $0,0 \%$ & $9,1 \%$ & $14.29 \%$ & $11,1 \%$ \\
\hline \multirow{2}{*}{$58-68$} & 9 & 2 & 6 & 1 & 4 & 3 & 25 \\
\cline { 2 - 8 } & $4,8 \%$ & $3,0 \%$ & $7,5 \%$ & $3,2 \%$ & $7,3 \%$ & $14.28 \% \%$ & $5,7 \%$ \\
\hline \multirow{2}{*}{69} & 3 & 0 & 3 & 0 & 0 & 0 & 6 \\
\hline \multirow{2}{*}{ Total } & $1,6 \%$ & $0,0 \%$ & $3,8 \%$ & $0,0 \%$ & $0,0 \%$ & $0,0 \%$ & $1,4 \%$ \\
\cline { 2 - 8 } & 187 & 67 & 80 & 31 & 55 & 21 & 441 \\
\hline
\end{tabular}

Table13 shows that people between 36 - 46 and 47 - 57 use the revenue yielded by these goods to pay their children's school fess, this is understandable because they significantly have children of school-going age. This 
strategy works because of the insufficient income they earn: about 70.76\% earn below 100,000frs CFA which is very insufficient to carter for their families. It is worth-noting that these categories of persons have more children. It is also observable that the goods are used to benefit the children of mostly young people. Their children use them for leisure activities, feeding and health-care unlike the other categories of persons. Therefore, we notice that the younger one is, the more the resources will be used to impact the lives of one's children. We also observe that middle age persons, retired persons and old persons use theirs to make their children travel. It is also interesting to note here that retired persons use theirs for feeding. This is because they do not have any stable income.

Therefore, the resources impact people's children's lives differently depending on their age. It is beneficial to younger people's children than the older one's children. There is a statistical relationship between one's age and how the goods impacts ones children (Value $=85,848 \cdot \mathrm{DF}=55$, Asymp. Sig. $(2$-sided $)=, 005)$

\section{Conclusion}

There are significant income varieties among two age groups: 25-35 years who significantly earn the lowest income and those who are between 36-46 years, who also significantly earn the highest income. This research shows that the older one is, the higher the income one will earn per month and vice versa. There is a very significant correlation between age and the amount of money one earns. Equally, the younger one is, the higher the probability that one has obtained a higher educational level and vice versa because unlike the older generation, the younger generation have the opportunity to go to school. Education is not a significant determinant of income because, the older one is, the higher one earns: younger people earn lower than older persons although they are more educated than them.

There are significant income varieties among the two age groups, 25-35 and 36- 46 because of the varieties of the activities that they do. Those who are between 47-57 are also only significantly civil servants while those who are between 36-46 are not only significantly civil servants but also farmers. That is why they earn the highest income monthly. This means that, the older one becomes, the less active he becomes in income generating activities and the younger one is, the more income generating activities he does. Younger people significantly diversify their economic activities. As a consequence, those who are between 36-46 have all the foodstuff for their subsistence and vary their meals more than four times per week. More so, the age group 47-48 stocked more foods than the other age-groups. Much older persons especially those who are on retirement, that is, those between $58-68$ and those above 69 years significantly vary their meals once because of lower income.

Generation plays a role in the choice of where one treats oneself when one is sick while the younger generation prefers street doctors; the older generation prefers a traditional doctor. Much older persons above 69 years either significantly combine street medication with either hospital or traditional treatment. In either case, it is interesting to note that they end up in the hospital. There is a statistical relationship between age and health-seeking behavior. Although young people do not significantly live in apartments and storey buildings and people above 36 significantly live in apartments and storey-buildings, there is no statistical relation between type of housing and age.

The age-groups: $25-35$ and 36-46 have a lot of significant variations, that is, they significantly have people who have households where two, three and above five persons live in a room. Only the above two age-groups significantly have households which have more than five persons per room. The age-group 58-68 do not significantly have households with only one or two persons inhabiting it, they significantly have three and four persons inhabiting a room and do not significantly have five persons per room.

Middle age persons (36 - 46 and $47-57)$ significantly possess more durable goods than the other categories. This is not a coincidence because they significantly earn above 154,000frs CFA. Although those above 69 years also significantly earn above 154,000frs CFA, they only significantly possess a telephone and a computer. Those between 58 - 68 years old significantly possess a refrigerator and those between $25-35$ only significantly possess a telephone. Equally, residents who are between 36-46 significantly possess more fixed and mobile goods because they significantly earn more. However, other factors play in the consumption of durable goods rather just income because those who are between $47-57$ significantly earn above 154,000 frs CFA but they own less number of durable goods than those who are between $36-46$.

Those who are younger (below 25 years and 36- 46) significantly get their possession through inheritance. Apart from those who are below 25 years, the rest significantly purchase the goods using their savings. We discovered that middle-age persons do not take loans, that is, those who are between $36-46$ and $47-57$ while those who are younger, that is, below 36 years and above 57 years significantly take loans to buy the above goods. Those who are between $36-46$ significantly buy theirs through inheritance and savings while those who are between $47-57$ mostly through purchase and endownment. There is significantly no correlation between age and the means used to obtain the mobile and immobile goods. We also discovered that people below 25years and those between $47-57$ and those above 69 use their goods as prestige. That means the goods becomes an object of conspicuous consumption, that is, use to show-off ones wealth and to distinguish oneself from the other persons. What is surprising is that younger persons despite their low-income still afford to buy luxury goods. There is a relationship between age and reasons why they possess both mobile and immobile goods.

It was also observable that the goods are used to benefit the children of mostly young people. Their children use them for leisure activities, feeding and health-care unlike the other categories of persons. Therefore we notice that the younger one is, the more the resources will be used to impact the lives of one's children. We also observe that middle age persons, retired persons and old persons use theirs to make their children travel. It is also interesting to note here that retired persons use theirs for feeding. This is because they do not have any stable income. 


\section{References}

Chambers, R. (1995). Poverty and livelihoods: whose reality counts? ID discussion paper, 347. University of Sussex: Brighton: IDS.

Chambers, R. and Conway, G. (1992). Sustainable rural livelihoods: practical concepts for the 21st century. IDS discussion paper, 296. University of Sussex: Brighton: IDS.

Diana, C. (2003). Sustainable Livelihoods Approaches: Progress and Possibilities for Change possibilities for change. Available: www.eldis.org/about/contribute.htm

Diniz (2013). Livelihood strategies in settlement projects in the Brazilian Amazon: Determining drivers and factors within the Agrarian reform program. Journal of Rural Studies, 32: 196-207.

Frank, E. (2000). The determinants of rural livelihood diversification in developing countries. The Journal of Agricultural Economics, 51(2): 289-302.

Gasselin, P., 2012. "Amend sustainable rural livelihoods' is it pertinent? In Pierre Marie Bosc and Jean Michel Sourisseau's paper: Describing the diversity of the system in the conference: From households to territories concepts and methodologies. ART-Dev Saint charles."

Koczberski, G., Curry, G. N. and Gibson, K. (2001). Improving Productivity of the S-mallholder Oil Palm Sector in Papua New Guinea. RSPAS, Australian National University.

Nanche, B.-R. (2021). Gender Difference and Women's Quality of Life in Maroua-Cameroon in advances in education, ICT and Innovation: Issues for Business and Social Enhancing. DYKINSON, Madrid: Francisco Javier Lena-Acebo, María Elena García-Ruiz. 201-08.

Scoones, I. (2009). Livelihoods perspectives and rural development. The Journal of Peasant Studies, 36(1): 171-96.

Tittonell, P., Muriuki, A., Shepherd, K. D., Mugendi, D., Kaizzi, K. C., Okeyo, J., Ver-chot, L., Coe, R. and Vanlauwe, B. (2010). The diversity of rural livelihoods and their influence on soil fertility in agricultural systems of East Africa - a typology of smallholder farms. Agricultural Systems, 103(2): 83-97. 